\title{
Price Transmission Differences between Conventional and Organic Products
}

\author{
Elham Darbandi ${ }^{1}$, Sayed Saghaian ${ }^{2}$ \\ ${ }^{1,2}$ Department of Agricultural Economics, University of Kentucky, Lexington, KY 40506, United States \\ Email: elham.darbandi@uky.edu
}

\begin{abstract}
In a competitive market, a rise in output prices at the wholesale level is expected to be transferred to the consumers via retailers. We have an asymmetric price transmission when an increase in the producer price transfers faster and stronger to the consumers comparing to a reduction in the producer price. The research question here is how product heterogeneity and differentiation can affect the price transmission in the carrots markets. Carrots consumption in the U.S. has been increasing significantly over the past few decades. We investigate the price linkages of carrots at terminal and retail levels for two different qualities of this product, organic and conventional. According to the VECM model results, the speed of price adjustment in the conventional carrot market is 0.354 in absolute value, while for the organic carrot market it is 0.026 . This result is an indication of asymmetric price transmission with respect to speed. It shows that the price adjustment in the organic carrot market is relatively slow, pointing to inefficiency in this market. These results have important policy implications, especially in case of price shocks, there could be differential welfare consequences for both consumers and producers.
\end{abstract}

Keywords: Asymmetric Price Transmission, Organic Products, Product Heterogeneity

\section{Introduction}

There is a general belief that most agricultural markets are perfectly competitive, meaning that a homogeneous product is produced by many sellers and for many buyers who are well informed about prices. The market is characterized by free entry and exit, with producers obligated to be price takers. In a competitive market, a rise in input costs or output price at the wholesale level is expected to be transferred to the consumers via retailers. Similarly, a reduction is also expected to be reflected fully in the price paid by the consumers at the retail level. In the economic literature, the price linkage between two markets is known as price transmission. This relation may be symmetric or asymmetric. For example, asymmetry exists when an increase in the producer price transfers faster and stronger to the consumers comparing to a reduction in the producer price.

Previous research articles discussed that there are some factors causing asymmetric price transmission to happen. Six factors affecting the asymmetric price transmission are listed by Conforti (2004): transaction/transportation costs, market power, increasing returns to scale in production, product heterogeneity and differentiation, exchange rates, and border and domestic policies. Despite the fact that most of these factors have received a wild attention in the price transmission literature (Goodwin and Holt, 1999; Girapunthong et al., 2003; Tiffin and Dawson, 2000; Darbandi, 2018), product heterogeneity and differentiation has been ignored and there are only a few recent studies that consider this issue. For instance, Surathkal et al. (2014) examined the price relationship in the beef market accounting for product differentiation in cuts and quality grades.

The question of this research is how product heterogeneity and differentiation can affect price transmission in the agricultural markets. Specifically, the focus will be on the organic and conventional products. Researchers argue that since organic and non-organic products are qualitatively differentiated, therefore different price dynamics can exist in each market (Würriehausen, et al., 2015). Nemati and Saghaian (2018) argue that organic market is a thin market which means there are few buyers or sellers in this market and therefore price discovery is a challenge in such a market. In addition, learning the price dynamic between organic and conventional markets has an importance for both policy makers and participant of the market. 
This study contributes to the literature by considering price transmission in the organic and conventional carrots as two differentiated products. In the case of price changes in the carrot markets, adjustments in prices of organic and conventional carrots may be different. The study of organic agriculture products can provide insights and help to develop new programs for producers and agribusinesses for potential different consequences of price shocks in conventional and organic markets.

\section{The Carrot Market}

One of the most effective sectors in leading an economy to economic growth is the agricultural sector (Tahamipour and Mahmoudi, 2018). Considering the importance of carrot in this sector, the 7th most consumed fresh vegetable in the U.S. is carrot and is mainly consumed fresh (Naeve, 2015). Carrot consumption has been increasing over the past few decades. Some factors that directly affect the per capita carrot consumption include immigration trends, change in lifestyle and preferences, and shifts in income (Lucier and Lin, 2007). Consumption of fresh carrots was about 8.5 pounds per person in 2014, in contrast, consumption of frozen carrots was only 0.7 pounds per person (Vegetable and Pulses Outlook, 2015). Based on the USDA 2014 survey, 25,379,000 (CWT) was produced in the U.S that is equivalent to $671,656,000$ in terms of dollar value and the amount of yield was 342 (CWT / ACRE).

As the third-leading producer of all carrots during last decade, the United States produced about 4 percent of the world carrot production, just behind Russia. It is while China by producing 4,072,854 produced 45 percent of the world's carrots (FAOstat, 2012). During 2013-2015 the U.S. growers produced an annual average of 2.46 billion pounds of carrots. The average price was around 0.3 (dollar/pound). California produced 2 billion pounds merely. Other important states in producing carrots are Michigan, Texas, Colorado, Georgia and Washington during 2013-2015. Totally, the U.S has produced more than 322 (1000 tonnes) carrots for processing over 2013-2015 and Washington and Wisconsin are the leader states in producing carrot for processing (USDA, 2016). Figure 1 shows the trend of carrots production in the U.S during 1990-2013.

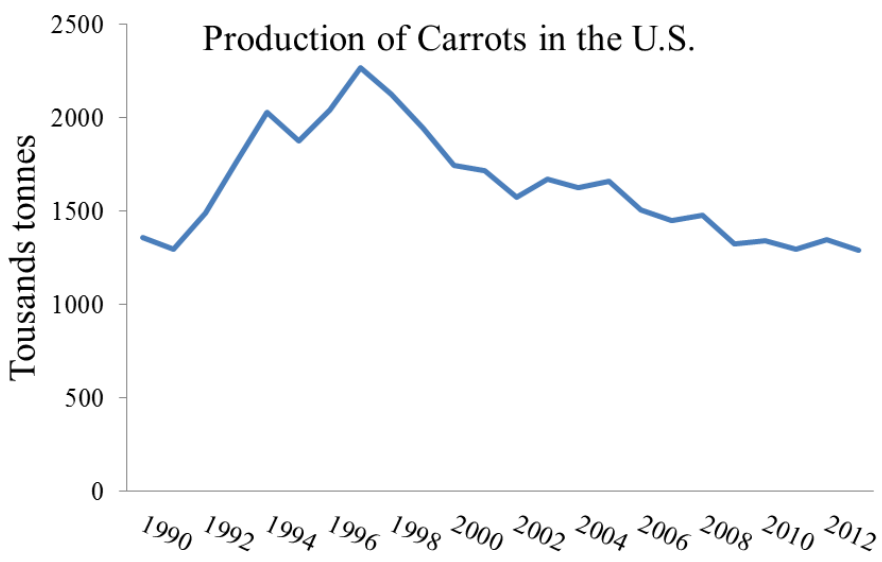

Figure 1. Production of Carrots in the U.S. 1990-2013(Source: Research findings based on FAOstat database)

After 1997, the U.S. experienced a reduction in the area harvested and carrots production. It is while the yield of this commodity has an increasing trend over the same period (Figure 2).

About the carrots trade, approximately 9.2 percent of the carrot supply produced was exported in 2013 (Naeve, 2015) and based on FAO database, the U.S. was the second top exporter of carrots after China, exporting more than 117 thousand tonnes, equivalent to more than 142 million dollars in 2013. Based on the most recent production and price averages, the estimated gross value for fresh market carrot production is $\$ 6,400$ per acre. The costs of carrot production vary and depend on the production location and the level of mechanization. Share of world production for the carrots is shown in Figure 3. The average share of the U.S. in 2012 is 3.6 percent. 


\section{Yeild of Carrots in the U.S.}

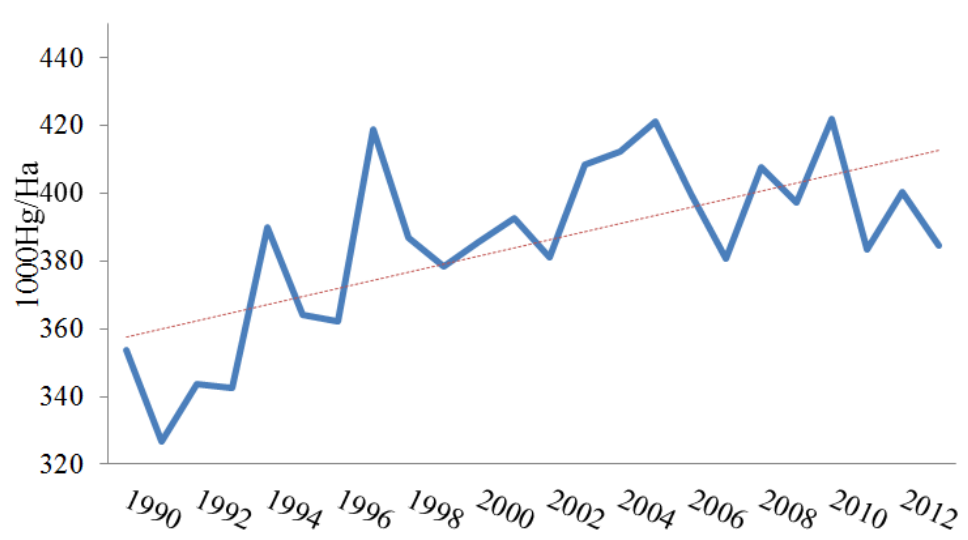

Figure 2. Yield of Carrots in the U.S. 1990-2013 (Dashed line is trendline) (Source: Research findings based on FAOstat database)

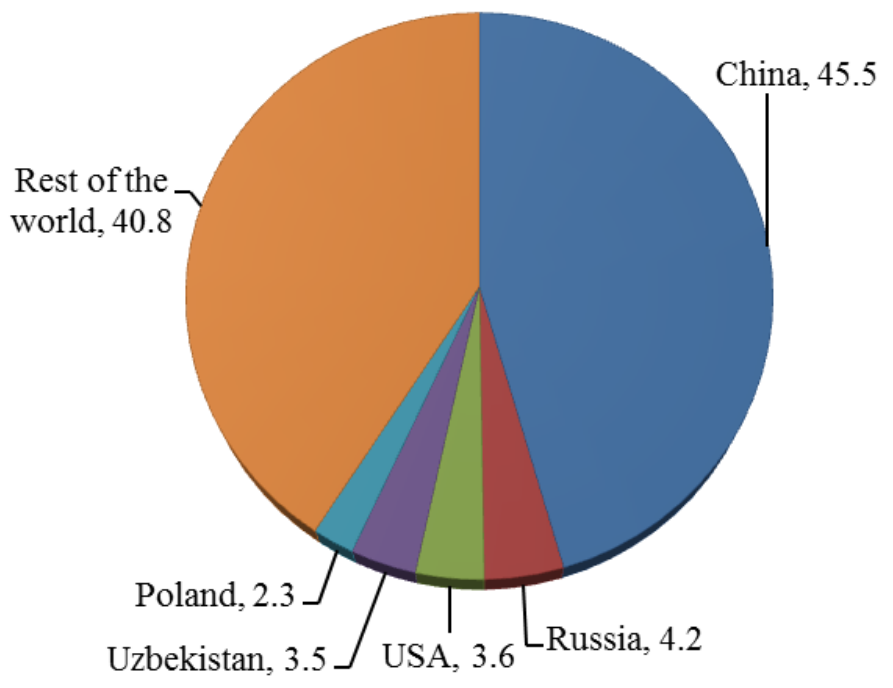

Figure 3. Share of production, 2012

(Source: Authors calculation from FAOSTAT, Food and Agriculture Organization, United Nations.)

\section{Methodology and Data}

In this research, we investigate the impacts of a price change in terminal market on the retail level prices of each market separately, focusing on the short-run dynamics of price adjustment and price transmission. One of the appropriate models to capture the short-run dynamics of price adjustment is the Vector Error Correction Model (VECM). This model not only allows estimating the short-run speed of price adjustments, but also preserves the long-run relationships among the variables (Saghaeian et al., 2007; Mahmoudi \& Guerrero, 2016). To check the stationary of the price series and market integration between the two markets, Augmented Dickey-fuller test and Johnsen's cointegration test are used respectively (Nemati \& Saghaian, 2018). After testing the stationary level of the variables, the cointegration between them will be investigated if they are integrated of order one (Mahmoudi, 2017). As Engle and Granger (1987) discussed, two I(1) series are said to be cointegrated if there is some linear combination of the two series which leads to a stationary trend or integration of zero degree. In other words, cointegrated series are related to each other over time. To check this, Johansen cointegration test is applied to our data series. As Arshad and Hameed (2014) discussed in their paper, Johansen (1988) used the VECM approach as a starting point for estimation: 


$$
Y_{t}=\mu+\sum_{i=1}^{P} A_{i} Y_{t-i}+\varepsilon_{t}
$$

In equation (1), $\varepsilon_{\mathrm{t}}$ is an independent identical error term (i.i.d). The VAR model can be parameterized in a VECM form by solving the change in $\mathrm{Y}_{\mathrm{t}}$ in the following equation:

$$
\Delta Y_{t}=\mu+\sum_{i=1}^{P} \Gamma_{i} \Delta Y_{t-i}-\Pi Y_{t-i}+\varepsilon_{t}
$$

The long-run information can be found in a matrix $\Pi$, where the rank of the matrix determines the number of cointegrating relationships. If the rank of matrix $\Pi$ equals to $p$ (the size of the $Y_{t}$ matrix), then the variable $Y_{t}$ is stationary. If the rank is less than $p$ but greater than zero, then some independent unit roots exist. If p equals to zero, then all the unit roots are independent. If the rank $\mathrm{r}$ is $0<\mathrm{r}<\mathrm{p}$, then $\mathrm{p}$ can be decomposed using a reduced rank regression into $\Pi=\alpha \beta^{\prime}$. To test the rank of matrix $\Pi$, the trace and the maximum eigenvalue test statistics are used.

The data used in this study is the weekly prices of organic and conventional carrots. The sample period extends from the first week of Jan 2012 to the last week of Dec 2014. Prices are used at both the retail and terminal market levels. The weekly data has been chosen for this study since the frequency of data is important to investigate the relationship between prices.

For retail prices, national level prices have been selected. However, prices at national level in the terminal market were not available; so Chicago prices are used as a representative of terminal markets. The data is reported by the agricultural marketing service of the United States Department of Agriculture (USDA) database. Also, the logarithm of prices has been used instead of level of prices. As Dawson and Tiffin (2000) and Banerjee et al. (1993) discussed, it is common to use logarithms in order to find cointegration relationships between different variables. The reason is that with trending data, the relative error might decline over time. Furthermore, Augmented Dickey-Fuller (ADF) stationary test has been used to avoid low power regressions.

\section{Results and Discussion}

According to the ADF test, the retail and terminal market price series are stationary at first difference. The results of cointegration test based on the two rank tests, trace and maximum eigenvalue tests, indicate that we can reject the null hypothesis of no cointegration in the long-run. Therefore, there is a relationship between the wholesale and the retail prices over time. In other words, prices will converge to each other in the long-run.

The results of the stationary test are shown in Table 1, where the number of lags has been chosen by Schwarz information criteria. The unit root test has been done by including trend and intercept. However, the results without including either trend or intercept are also the same except of a small change in critical values. Here we only report the results for organic carrots since the same results have been achieved for non-organic carrots.

Table 1. Stationary Test for Organic Carrots

Null Hypothesis: first difference of variable has a unit root

\begin{tabular}{llll}
\hline Variable & ADF test Statistic & t- statistic & probability \\
\hline $\mathrm{D}$ (Terminal Prices) & With Trend and Intercepts & $-12.352^{*}$ & 0.000 \\
$\mathrm{D}$ (Retail Prices) & With Trend and Intercepts & $-11.38^{*}$ & 0.000 \\
\hline Test critical Value at $1 \%$ level $=-4.019$ & & \\
(*) Significant at 1\% level & &
\end{tabular}

As it can be seen in Table 1, both the retail level price series and terminal market price series for organic carrots are stationary at first difference. Therefore they are both $\mathrm{I}(1)$ and the next step is to investigate the existence of any cointegration.

The results of cointegration test are reported in Table 2. The results of the model which has been chosen to report here, is with no deterministic trend; while including trend would lead to the same results. As it can be seen in Table 2, the results indicate that the null hypothesis of no cointegration in the long-run can be rejected. Therefore, there is a long-run relationship between prices over time. 
Table 2. Johansen Cointegration Test

Unrestricted Cointegration Rank Test (Trace)

\begin{tabular}{|c|c|c|c|c|}
\hline $\begin{array}{l}\text { Hypothesized } \\
\text { No of CE }(\mathrm{S})\end{array}$ & Eigenvalue & Trace statistic & 0.05 critical value & Probability \\
\hline None* & 0.207 & 41.295 & 20.261 & 0.000 \\
\hline At most 1 & 0.371 & 5.788 & 9.164 & 0.2077 \\
\hline \multicolumn{5}{|c|}{$(*)$ denotes rejection of the hypothesis at the 0.05 level } \\
\hline \multicolumn{5}{|c|}{ Unrestricted Cointegration Rank Test (Maximum Eigenvalue) } \\
\hline $\begin{array}{l}\text { Hypothesized } \\
\text { No of } \mathrm{CE}(\mathrm{S})\end{array}$ & Eigenvalue & Trace statistic & 0.05 critical value & Probability \\
\hline None* & 0.207 & 35.5066 & 15.892 & 0.000 \\
\hline At most 1 & 0.371 & 5.788 & 9.164 & 0.2077 \\
\hline
\end{tabular}

$(*)$ denotes rejection of the hypothesis at the 0.05 level

As we mentioned before, all the variables are stationary at the first difference and a long-run relationship exists between them. Therefore, the VECM approach is an appropriate model to use. The results of this model are reported in Table 3.

Table 3. The Empirical Estimates of Price Adjustment Speed

\begin{tabular}{lll}
\hline Variable & Organic Carrots & Non-Organic \\
\hline Error correction term & $-0.354^{* * *}$ & $-0.026^{* * *}$ \\
Model diagnostics & $(-3.831)$ & $(-6.246)$ \\
R-squared & 0.30 & 0.30 \\
Akaike AIC & -1.16 & -2.80 \\
Schwarz SC & -1.06 & -2.75 \\
\hline *** indicates significance level at 1\% & \\
- Numbers in parenthesis are t- Statistics
\end{tabular}

According to the VECM approach, the speed of price adjustment in the conventional market is 0.354 in absolute value; while for the organic market, it declines to 0.026 in absolute value. Therefore, the empirical estimation of the price adjustment speed indicates that the prices in the conventional market adjust faster than the prices in the organic market in response to a price shock. This result is an indication of asymmetric price transmission with respect to the speed.

The results of this study would have an important application for policy makers. For instance, if a price policy is set to support consumers in a market, say the conventional market, we cannot except to have the same welfare change effects on the organic market consumers of the same product. Also, since the prices in the conventional market adjust more quickly to the long-run equilibrium, it could be interpreted as a signal of more concentration and higher market power in the organic market with slower price adjustment. However, the results of this study might not be directly a test for market power and further research can be done in this area.

\section{References}

1. A, Banerjee, J. Dolado, J.W. Galbrailh, and D.F. Hendry. Cointegration, Error Correction and the Econometric Analysis of Time Series. Oxford University Press. Oxford. 1993

2. B. K. Goodwin and M. T. Holt. "Price transmission and asymmetric adjustment in the US beef sector." American Journal of Agricultural Economics, pp. 630-637, 1999.

3. E. Darbandi, "Price transmission analysis for Nicaragua rice market," International Journal of Food and Agricultural Economics, Vol. 6, No. 1, pp. 85-94, 2018. 
4. F. M. Arshad and A.A. Hameed. "Price Transmission in Selected Malaysian Fruits Markets." American Journal of Applied Sciences 11(3), pp: 347-355, 2014.

5. Food and Agriculture Organization of the United Nations (FAO).2015. Online. Available at http://faostat3.fao.org/home/E. (Acceded March 5, 2015)

6. G. Lucier and B.H. Lin. Factors Affecting Carrot Consumption in the United States. Washington, DC: U.S. Department of Agriculture/ Outlook Report from the Economic Research Service, Pub. No. VGS319-01.2007

7. L. Naeve, carrots.2015. "Agricultural Marketing Resource Center (AGMRC)." Online. Available at http://www.agmrc.org/commodities-products/vegetables/carrots/ [Retrieved April 1, 2015].

8. M. Tahamipour and M. Mahmoudi. "The Role of Agricultural Sector Productivity in Economic Growth: The Case of Iran's Economic Development Plan." Research in Applied Economics 10.1, 2018.

9. M. Mahmoudi, "Three Essays in Macroeconomics." PhD diss., 2017.

10. M. Mahmoudi and F. Guerrero. "The transmission of the US stock market crash of 2008 to the European stock markets: an applied time series investigation." American Journal of Economics 6.4, pp. 216-225, 2016.

11. M. Nemati and S. H. Saghaian. "Dynamics of Price Adjustment in Qualitatively Differentiated U.S. Markets: The Case of Organic and Non-organic Apples." Journal of Agribusiness 36.1, 2018.

12. N. Girapunthong, J. J. VanSickle, and A. Renwick. "Price asymmetry in the United States fresh tomato market." Journal of Food Distribution Research, 34.3, pp. 51-59, 2003.

13. N. Würriehausen, R. Ihle, and S. Lakner. "Price Relationships between Qualitatively Differentiated

14. Agricultural Products: Organic and Conventional Wheat in Germany." Agricultural Economics 46 (2), pp. 195209, 2015.

15. P. Conforti, "Price transmission in selected agricultural markets," FAO Commodity and trade policy research working paper 7, 2004.

16. P. Surathkal, C. Chung, and S. Han. "Asymmetric Adjustments in Vertical Price Transmission in the US Beef Sector: Testing for Differences among Product Cuts and Quality Grade." Selected paper, Agricultural and Applied Economics Association annual meeting, Minneapolis, MN, July. 2014.

17. R. F. Engle and C.W. Granger. "Co-integration and Error Correction: Representation, Estimation and Testing." Econometrica 55, pp. 251-276. 1987

18. R. Tiffin and P. J. Dawson. "Structural breaks, cointegration and the farm-retail price spread for lamb." Applied economics 32 , no. 10, pp. 1281-1286, 2000.

19. S. H. Saghaian, L. A. Meyer, and A. D. Spaulding. "Beef safety shocks and dynamics of vertical price adjustment: The case of BSE discovery in the US beef sector." Agribusiness: An International Journal 23.3, pp. 333-348, 2007.

20. U.S. Department of Agriculture - Agricultural Marketing Service. 2015. Internet Site:

https://www.marketnews.usda.gov/mnp/fv-home. (Acceded March 1, 2015)

21. U.S. Department of Agriculture -Natural Agricultural Statistics service. 2016. Vegetable 2015 Summary. 